\title{
Perbedaan tinggi badan sebelum tidur dan setelah bangun pagi pada masyarakat subetnis Minahasa di Desa Senduk
}

\author{
${ }^{1}$ Magdalena I. Simanullang \\ ${ }^{2}$ George N. Tanudjaja \\ ${ }^{2}$ Djon Wongkar \\ ${ }^{2}$ Taufiq F. Pasiak
}

\author{
${ }^{1}$ Kandidat Skripsi Fakultas Kedokteran Universitas Sam Ratulangi Manado \\ ${ }^{2}$ Bagian Anatomi-Histologi Fakultas Kedokteran Universitas Sam Ratulangi Manado \\ Email: magdalenasimanullang120111172@gmail.com
}

\begin{abstract}
Anthropometry is a measurement of certain parts of human body including height. This study was aimed to obtain the difference in height between after waking up in the morning and before going to bed at night among Minahasan sub-ethnic people at Senduk village. This was an analytical study with a cross-sectional design. Sampels were obtained by using purposive sampling method. There were 65 people as subjects. The results showed that the heights after waking up in the morning were longer than the heights before going to bed at night with an average of $1-2 \mathrm{~cm}$ for both sexes. The Wilcoxon test showed a significant difference between the heights after waking up in the morning and the heights before going to bed at night ( $\mathrm{p}=0.002$ for males and $\mathrm{p}=0.000$ for females). Conclusion: There was a significant difference between the heights after waking up in the morning and the heights before going to bed at night. The heights after waking up in the morning were longer than the heights before going to bed at night.
\end{abstract}

Keywords: height, after waking up in the morning, before going to bed at night

\begin{abstract}
Abstrak: Antropometri merupakan sebuah alat ukur yang digunakan untuk mengukur bagian-bagian tubuh manusia termasuk tinggi badan. Penelitian ini bertujuan untuk mendapatkan perbedaan tinggi badan sebelum tidur dan setelah bangun pagi pada sub-etnis Minahasa di Desa Senduk. Jenis penelitian ialah analitik dengan desain potong lintang. Sampel diambil secara purposive sampling sebanyak 65 orang. Hasil penelitian mendapatkan bahwa tinggi badan setelah bangun pagi lebih panjang dibandingkan sebelum tidur malam hari dengan rerata perbedaan 1-2 $\mathrm{cm}$ untuk kedua jenis kelamin. Hasil uji Wilcoxon mendapatkan perbedaan bermakna antara tinggi badan setelah bangun pagi dan sebelum tidur ( $\mathrm{p}=0,002$ untuk laki-laki dan $\mathrm{p}=0,000$ untuk perempuan). Simpulan: Terdapat perbedaan bermakna antara tinggi badan setelah bangun pagi dan sebelum tidur malam hari. Tinggi badan setelah bangun pagi lebih pendek dibandingkan sebelum tidur malam hari.
\end{abstract}

Kata kunci: tinggi badan, sebelum tidur malam hari, setelah bangun pagi

Antropometri berasal dari bahasa Yunani anthropos yang berarti orang/manusia dan metron yang berarti ukuran. Menurut National Health and $N$ utrition Examiniton Survei (NHANES), antropemetri merupakan studi tentang pengukuran tinggi badan, berat badan, bahkan pengukuran bagian tubuh lainnya seperti lipatan kulit dan lingkar tubuh. ${ }^{1}$ Studi mengenai pengukuran antropometri telah dimulai sejak tahun 1960-an dan telah dilakukan di berbagai negara di dunia antara lain Jepang, New Guinea, Samoa, dan Afrika. Penelitianpenelitian antropometri di Indonesia sudah jarang dilakukan karena adanya kendala beberapa faktor, seperti biaya dan waktu. ${ }^{2}$. 
Pengukuran antropometri terdiri dari beragam pengukuran terhadap dimensi tubuh, salah satunya pengukuran linier atau tinggi badan. Tingi badan manusia akan terus bertambah mulai dari usia bayi sampai akhir proses maturasi tulang. Proses pertumbuhan pada bayi berlangsung sangat cepat dan setelah itu pertumbuhan linier masih berlanjut namun dengan kecepatan yang lambat. ${ }^{3}$

Growth spurt atau ledakan pertumbuhan adalah titik usia dimana terjadi lonjakan pertumbuhan yang sangat cepat dari usia sebelumnya dan terjadi selama masa pubertas. Ledakan pertumbuhan terjadi pada usia 12 tahun untuk anak perempuan dan 14 tahun untuk anak laki-laki. Selama masa growth spurt, pertumbuhan tinggi badan perempuan dapat mencapai $9 \mathrm{~cm}+1,03 \mathrm{~cm} /$ tahun dan mencapai tinggi rata-rata terakhir pada usia 16 tahun, sedangkan laki-laki dapat bertambah tinggi $10,3 \mathrm{~cm}+1,53 \mathrm{~cm} /$ tahun selama growth spurt sampai pada usia 18 tahun. Setelah melewati masa ini pertumbuhan masih terus terjadi tetapi berlangsung lambat sampai pertumbuhan pada lempeng epifisis berhenti. ${ }^{4}$

Saat ini banyak teori mengenai tinggi badan yang telah dikemukakan oleh para ahli berdasarkan penelitian yang dilakukan. Penelitian yang dilakukan oleh Artaria dari Departemen Antropologi Universitas Airlangga Surabaya menemukan bahwa terdapat perbedaan antara laki-laki dan perempuan dalam hal pengukuran antropometri seperti tinggi badan. Laki-laki cenderung lebih tinggi dari perempuan dikarenakan laju growth spurt pada lakilaki lebih besar daripada perempuan, walaupun growth spurt terjadi lebih dini dari perempuan. ${ }^{2}$

Selain itu, penelitian yang dilakukan oleh Roush et al. ${ }^{5}$ mendapatkan bahwa dapat terjadi pengurangan vertebral column height atau tinggi kolumna vertebralis saat melakukan latihan berjalan sejauh 3 mil. Iatridis et al. ${ }^{6}$ juga menemukan perubahan dapat terjadi pada kolumna vertebralis hewan percobaan tikus jika diberikan pebebanan tertentu pada kolumna vertebralis. Dari kedua penelitian di atas dapat diasumsikan terjadi perubahan tertentu pada saat pengukuran tinggi badan.

Tujuan penelitian ini ialah untuk melihat perbedaan tinggi badan yang diukur pada dua waktu berbeda, yaitu setelah bangun pagi dan sebelum tidur di malam hari pada sub-etnis Minahasa di Desa Senduk.

\section{METODE PENELITIAN}

Jenis penelitian ini ialah analitik dengan desain potong lintang. Penelitian dilaksanakan pada bulan Oktober-Desember 2015. Tempat penelitian yaitu di tempat tinggal masing-masing subjek penelitian. Dalam penelitian ini populasi ialah seluruh subetnis Minahasa di Desa Senduk berjumlah 65 orang. Pengukuran tinggi badan menggunakan microtoise atau staturemeter yang memiliki panjang $200 \mathrm{~cm}$ dengan ketelitian $0,1 \mathrm{~cm}$. Hasil penelitian disajikan dalam bentuk tabel menggunakan SPSS.

Analisis data dilakukan daengan cara univariat dan bivariat. Analisis univariat dilakukan untuk memperoleh gambaran tiap variabel, distribusi, frekuensi, sedangkan analisis bivariat dilakukan untuk menganalisis hasil dengan menggunakan uji Wilcoxon.

\section{HASIL PENELITIAN}

Penelitian dilakukan terhadap 65 orang sub-etnis Minahasa di Desa Senduk berusia 20-25 tahun pada tahun 2015.

Berdasarkan distribusi usia subjek penelitian didapatkan usia subjek penelitian berkisar antara 20-25 tahun dengan usia terbanyak yaitu 22 tahun ( $25 \%$ ).

Tabel 1. Distribusi subjek penelitian berdasarkan umur

\begin{tabular}{ccc}
\hline Usia & Jumlah subjek & $\mathbf{( \% )}$ \\
\hline 20 & 10 & $15 \%$ \\
21 & 15 & $23 \%$ \\
22 & 16 & $25 \%$ \\
23 & 11 & $17 \%$ \\
24 & 11 & $17 \%$ \\
25 & 2 & $3 \%$ \\
Total & 65 & $100 \%$ \\
\hline
\end{tabular}


Berdasarkan jenis kelamin subjek penelitian didapatkan subjek penelitian dengan jenis kelamin laki-laki berjumlah 37 orang $(57 \%)$ dan yang berjenis kelamin perempuan berjumlah 28 orang $(43 \%)$.

Tabel 2. Distribusi subjek penelitian berdasarkan jenis kelamin

\begin{tabular}{ccc}
\hline Jenis kelamin & Jumlah subjek & $\mathbf{( \% )}$ \\
\hline Laki-laki & 37 & $57 \%$ \\
Perempuan & 28 & $43 \%$ \\
Total & 65 & $100 \%$ \\
\hline
\end{tabular}

Tabel 3 memperlihatkan klasifikasi peningkatan tinggi badan, peningkatan terendah dan tertinggi, serta rerata peningkatan pada keseluruhan subjek penelitian laki-laki dan perempuan yang berjumlah 65 orang. Didapatkan bahwa peningkatan tinggi badan terbanyak yaitu 1-2 cm dengan jumlah 48 orang (74\%), peningkatan $<1 \mathrm{~cm}$ sebanyak 15 orang (23\%), dan peningkatan $>2 \mathrm{~cm}$ sebanyak 2 orang $(3 \%)$.
Tabel 3. Perbandingan peningkatan tinggi badan subjek penelitian laki-laki dan perempuan

\begin{tabular}{ccccc}
\hline $\begin{array}{c}\text { Jenis } \\
\text { kelamin }\end{array}$ & \multicolumn{3}{c}{ Peningkatan } & n \\
\cline { 2 - 4 } & $<1 \mathrm{~cm}$ & $1-2 \mathrm{~cm}$ & $>2 \mathrm{~cm}$ & \\
\hline Laki-laki & 10 & 27 & 0 & 37 \\
Perempuan & 5 & 21 & 2 & 28 \\
Total & 15 & 48 & 2 & 65 \\
\hline
\end{tabular}

Hasil uji penelitian pada Tabel 4 menunjukkan bahwa berdasarkan tinggi badan sebelum tidur dan setelah bangun pagi pada subjek berjenis kelamin laki-laki didapatkan 5 orang mengalami penurunan tinggi badan dan 32 orang mengalami pertambahan tinggi badan dari total subjek sebanyak 37 orang. Hasil sig. 2-tailed mendapatkan $\mathrm{p}=0,002 \quad(\alpha=0,05) \quad$ yang berarti terdapat perbedaan bermakna antara tinggi badan sebelum tidur dan setelah bangun pagi pada subjek berjenis kelamin laki-laki.

Tabel 4. Hasil perbedaan tinggi badan sebelum tidur dan setelah bangun pagi berdasarkan jenis kelamin laki-laki

\begin{tabular}{clcc}
\hline & & n & Asymp. Sig. (2-tailed) \\
\hline & Negative ranks & $5^{\mathrm{b}}$ &, 002 \\
TB post $(\mathrm{cm})-$ & Positive ranks & $32^{\mathrm{c}}$ & \\
TB pre $(\mathrm{cm})$ & Ties & $0^{\mathrm{d}}$ & \\
& Total & 37 & \\
\hline
\end{tabular}

Tabel 5. Hasil perbedaan tinggi badan sebelum tidur dan setelah bangun pagi berdasarkan jenis kelamin perempuan

\begin{tabular}{clcc}
\hline & & n & Asymp. Sig. (2-tailed) \\
\hline & Negative Ranks & $1^{\mathrm{b}}$ & 0,000 \\
TB post $(\mathrm{cm})-$ & Positive Ranks & $27^{\mathrm{c}}$ & \\
TB pre $(\mathrm{cm})$ & Ties & $0^{\mathrm{d}}$ & \\
& Total & 28 & \\
\hline
\end{tabular}

Tabel 5 menunjukkan adanya pertambahan tinggi badan sebelum tidur malam dan setelah bangun pagi pada 27 subjek perempuan sedangkan 1 orang mengalami penurunan. Hasil sig. (2-tailed) menunjukkan hasil $\mathrm{p}=0,00(\alpha=0,05)$ yang berarti terdapat perbedaan bermakna antara tinggi badan sebelum tidur dan setelah bangun pagi pada subjek berjenis kelamin perempuan.

Tabel 6 menunjukkan selisih nilai rerata tinggi badan sebelum tidur malam 
hari dan setelah bangun pagi pada subjek laki-laki dan pada subyek perempuan dengan nilai sig. 2 -tailed $p=0,072(\alpha=0,05)$ yang berarti terdapat tidak terdapat perbedaan bermakna dari selisih nilai rerata tinggi badan sebelum tidur malam hari dan setelah bangun pagi pada kedua jenis kelamin.

Tabel 6. Hasil selisih tinggi badan sebelum tidur malam hari dan setelah bangun pagi antara subyek laki-laki dan perempuan

\begin{tabular}{clcc}
\hline \multicolumn{2}{c}{ Jenis kelamin } & n & $\begin{array}{c}\text { Sig. (2- } \\
\text { tailed) }\end{array}$ \\
\hline \multirow{2}{*}{ Selisih TB } & Laki-laki & 37 &, 072 \\
$(\mathrm{~cm})$ & Perempuan & 28 & \\
& Total & 65 & \\
\hline
\end{tabular}

Hasil uji Wilcoxon menghasilkan nilai $\mathrm{p}=0,000$ sehingga dapat disimpulkan bahwa terdapat perbedaan bermakna antara tinggi badan sebelum tidur dan setelah bangun pagi pada kedua jenis kelamin (Tabel 7).

Tabel 7. Hasil tinggi badan sebelum tidur dan setelah bangun pagi pada subyek laki-laki dan perempuan

\begin{tabular}{llcc}
\hline & & n & $\begin{array}{c}\text { Sig. (2- } \\
\text { tailed) }\end{array}$ \\
\hline & Negative ranks & $6^{\text {a }}$ & 0,000 \\
TB post $(\mathrm{cm})$ & Positive ranks & $59^{\mathrm{b}}$ & \\
- TB pre cm) & Ties & $0^{\mathrm{c}}$ & \\
& Total & 65 & \\
\hline
\end{tabular}

\section{BAHASAN}

Sampel yang diambil pada penelitian ini ialah sub-etnis Minahasa di Desa Senduk berusia 20-25 tahun berjumlah 65 orang. Seluruh sampel yang diambil juga telah memenuhi kriteria inklusi dan menandatangani surat persetujuan penelitian.

Data distribusi menurut usia (Tabel 1) menunjukkan bahwa sebagian besar sampel berusia 22 tahun (25\%) diikuti dengan usia 21 tahun (23\%), usia 23 dan 24 tahun (masing-masing 17\%), usia 20 tahun (15\%), dan usia 25 tahun (3\%). Bila dilihat dari usia pertumbuhan tinggi badan, seluruh subyek penelitian telah berada pada usia dimana pertumbuhan tinggi badan telah berhenti. ${ }^{7}$ Dengan demikian dapat disimpulkan bahwa perbedaan tinggi badan yang didapatkan pada seluruh subyek bukan disebabkan oleh pengaruh terjadinya proses pertumbuhan.

Data distribusi menurut jenis kelamin (Tabel 2) memperlihatkan tidak terdapat perbedaan besar antar jumlah subyek lakilaki dan perempuan, yaitu jumlah subyek berjenis kelamin laki-laki sebanyak 37 orang $(57 \%)$ dan perempuan 28 orang $(43 \%)$.

Peningkatan yang terjadi dari pengukuran tinggi badan sebelum tidur malam hari dan setelah bangun pagi (Tabel 3) dibagi dalam 3 kategori yaitu peningkatan $<1 \mathrm{~cm}, 1-2 \mathrm{~cm}$, dan $>2 \mathrm{~cm}$. Dapat pula dilihat peningkatan tertinggi pada laki-laki dan perempuan paling banyak tergolong kategori 1-2 cm. Penelitian sebelumnya oleh Pattudju mendapatkan rata-rata peningkatan tinggi badan yang terjadi pada laki-laki yaitu sebesar $1,5 \mathrm{~cm}$ sedangkan pada perempuan $1,6 \mathrm{~cm}$. Hal ini disebabkan karena beberapa faktor yang memengaruhi efek pemipihan diskus intervertebralis yang berlangsung sepanjang hari. ${ }^{8}$

\section{SIMPULAN}

Dari hasil penelitian pada sub-etnis Minahasa di Desa Senduk dapat disimpulkan bahwa terdapat perbedaan tinggi badan yang bermakna pada pengukuran sebelum tidur malam hari dan setelah bangun pagi dimana terjadi peningkatan tinggi badan jika diukur pada pagi hari dibandingkan pengukuran pada malam hari.

\section{SARAN}

Disarankan untuk penelitian lanjut mengenai berbagai jenis latihan yang berhubungan dengan pengurangan vertebral column height $(\mathrm{VCH})$.

\section{DAFTAR PUSTAKA}

1. National Health and Nutriton Examination Survey. Anthopometry Procedures Manual;2004:1 
2. Artaria MD. Perbedaan antara laki-laki dan perempuan: Penelitian antropometri pada anak-anak umur 6-19 tahun. Jurnal Kebudayaan Masyarakat dan Politik. 2010;22(4):343-9.

3. Wong DL. Buku Ajar Keperawatan Pediatrik (6th ed). Jakarta: EGC, 2008.

4. Harrison Prinsip-prinsip Ilmu Penyakit Dalam Vol. 1 (13th ed). Jakarta: EGC, 1999.

5. Roush JR, Kee M, Toeppe J. Change in vertebral column height $(\mathrm{VCH})$ at different distance intervals during a 3mile walk. North America Journal of
Sport Physical Therapy. 2008;3(3):145150.

6. Iatridis JC, Mente PL, Stroke IAF, Aroson D, Alini M. CompressionInduced Changes in Intervertebral Disc Properties in a Rat Tail Model. Spine. 1999;24(10):996-1002.

7. Batubara JRL. Adolescent Development. Sari Pediatri. 2010;12(1):21-9.

8. Pattudju RAT. Gambaran tinggi badan sebelum tidur dan setelah bangun pagi pada mahasiswa Fakultas Kedokteran Unsrat [Skripsi]. Manado: Universitas Sam Ratulangi; 2015. 